\title{
GROWTH RATES OF THE CHOKKA SQUID LOLIGO REYNAUDII D'ORBIGNY, 1845 (CEPHALOPODA: MYOPSIDA: LOLIGINIDAE) OFF SOUTH AFRICA, INVESTIGATED OVER TWO YEARS
}

\author{
COlletTe H. MWANANGOMBE ${ }^{1,2}$, DEON DURHOLTZ3 , DAWIT YeMANE ${ }^{3}$, \\ JEAN GITHAIGA-MWICIGI ${ }^{3}$, WARWICK H. H. SAUER ${ }^{2}$, MAREK R. LIPIŃSKII ${ }^{2,4 *}$
}

\footnotetext{
${ }^{1}$ National Marine Information and Research Centre (NatMIRC), Ministry of Fisheries and Marine Resources, P.O. Box 912, Swakopmund, Namibia; (1) https://orcid.org/0000-0002-0182-5421

2 Department of Ichthyology and Fisheries Science, Rhodes University, P.O. Box 94, 6140 Grahamstown, South Africa;

(1) WHHS https://orcid.org/0000-0002-9756-1757

${ }^{3}$ Branch, Fisheries Management, Department of Environment, Forestry and Fisheries, Foreshore, Rogge Bay, 8012, Cape Town, South Africa;

(1) DD https://orcid.org/0000-0002-3234-9798; 이 DY https://orcid.org/0000-0001-7293-2534;

(1) JGM https://orcid.org/0000-0003-4382-3966

${ }^{4}$ South African Institute of Aquatic Biodiversity (SAIAB), 11 Somerset Rd., 6140 Grahamstown,

South Africa (e-mail: lipinski@mweb.co.za);

(1) https://orcid.org/0000-0001-9362-4610

*corresponding author
}

ABSTRACT: Growth of adult chokka squid Loligo reynaudii d'Orbigny was modelled using mantle length and age data derived from samples collected over two years (2003 and 2004) from a single, large cohort of mature and spawning squid. A total of 588 statoliths were examined (310 males, 278 females) from individuals of 71-425 mm mantle length (ML). The maximum size of chokka squid was $425 \mathrm{~mm}$ ML for males and $263 \mathrm{~mm}$ ML for females. The Francis Growth Model and Linear Growth model were selected for further analysis from six models considered. Males and females attain similar ages, although mantle length-based daily growth rates ranged from 0.75 to 1.02 (0.88 quantile 50$) \mathrm{mm}$ /day for males and 0.32 0.45 (0.38 quantile 50$) \mathrm{mm} /$ day for females, explaining the sexual dimorphism apparent in the sizes of individuals of this species.

KEY WORDS: age; growth models; growth rates; length frequency

\section{INTRODUCTION}

Although the chokka squid (Loligo reynaudii d'Orbigny, 1845) can be considered one of the most comprehensively studied squid species worldwide, relatively few data on growth rates (absolute or relative) are currently available. Estimates of age and other important parameters such as growth rate, age-at-maturity and life span are crucial in the un- derstanding of the population dynamics of marine organisms (JACKSON 1990). The value of these parameters towards achieving sound management of fisheries in general and squid stocks in particular is well known and documented in a number of publications (HATANAKA 1986, BIGELOW 1992, ARKHIPKIN 1994, HATFIELD et al. 2001, GRIST \& JACKSON 2004, 
SChWARZ \& Perez 2010, Jin et al. 2019). Estimates for these parameters can be obtained from age estimates based on hard structures such as gladii, beaks and statoliths, which are shown to bear periodic growth increments (e.g. JiN et al. 2019).

A preliminary study of age and growth of the chokka squid L. reynaudii (LIPIŃSKI \& DURHOLTZ 1994) that used data from only 31 individuals, indicated significant differences between males and females. Reviews of chokka biology (SAUER et al. 2013, VAN DER VYVER et al. 2016, LIPIŃSKI et al. 2016) and

\section{MATERIALS AND METHODS}

Details of the sampling and statolith analyses are provided by LIPIŃSKI et al. (2020) and some details are repeated here. Details of images of increments, periodicity, validation for chokka species are provided in references given in LIPIŃSKI et al. (2020). The study was conducted on material sampled from the south-east coast of South Africa in the area between Plettenberg Bay $\left(24^{\circ} \mathrm{E}\right)$ and Port Alfred $\left(26^{\circ} \mathrm{E}\right)$, the main spawning grounds of the species. Squid were caught using hand jigging in 2003 and both hand jigging and trawling in 2004 (trawling: $36 \%$ of males and $57 \%$ of females collected in that year). All sampling was conducted on spawning grounds where mature squid move freely between spawning concentrations (see SAUER et al. 1992, LIPIŃSKI et al. 1998). Even small sampled individuals were mature (stage V) with few exceptions of maturity stage IV (LIPIŃSKI \& UNDERHILL 1995). All individuals were measured (mantle length in bins $1 \mathrm{~cm}$ below) and then randomly sub-sampled for statolith extraction. Length distributions of the squid sampled were visually compared with those from the overall survey; there were no differences between these distributions (LIPIŃSKI et al. 2020: fig. 6). Statoliths (both left and right) were dissected from fresh animals (LIPIŃSKI et al. 2020 - references therein) washed in distilled water and stored in $70 \%$ ethanol. Both statoliths were later airdried and prepared for light microscopy (LIPIŃSKI et al. 2020 - references therein). The statolith preparations were viewed under transmitted light using a Carl Zeiss Axioscope 5 compound microscope and photographed using a Carl Zeiss high resolution digital camera mounted on the microscope. An experienced statolith reader then conducted a single count with no repetitions of the total number of increments in better prepared statolith of the pair, using the digital images. A total of 613 statoliths were prepared for analysis, of which 588 were used for this study. The length and age data are summarised in Tables 1a and $1 \mathrm{~b}$ for easy reference. recent ageing study (LIPIŃSKI et al. 2020) provide no estimates of chokka squid growth rates.

This study aimed at providing growth rates of the chokka squid with age estimates derived from statolith daily increment analyses (details in LIPIŃSKI et al. 2020). Age data, coupled with the mantle length measurements of the aged individuals, are used to estimate growth rates of a large cohort of spawning squid, which is subject to exploitation and management (SAUER et al. 2013, VAN DER VyVer et al. 2016, LIPIŃSKI et al. 2016).

Six growth models (linear, exponential, power, Gompertz, Schnute and Francis) were initially considered, and fitted to the mantle length-at-age data. However, of the six models, only four yielded acceptable fits to the data. The Gompertz and exponential growth models could not be fitted to the data because numerical issues with no solutions were found, and these were not considered further. The models fitted are given below:

Linear growth model:

$$
\mathrm{ML}=\mathrm{a}+\mathrm{b}(\text { age })
$$

Power growth model:

$$
\mathrm{ML}=\mathrm{a}(\mathrm{age})^{\mathrm{b}}
$$

Francis growth model (OGLE 2016):

$$
\mathrm{ML}=\mathrm{L}_{1}\left(\mathrm{~L}_{3}-\mathrm{L}_{1}\right)\left[\frac{1-\mathrm{r}^{2\left(\frac{\mathrm{age} e-\mathrm{t}_{\mathrm{t}}-\mathrm{t}_{\mathrm{t}}}{1}\right)}}{1-\mathrm{r}^{2}}\right]
$$

where $r=\frac{L_{3}-L_{2}}{L_{2}-L_{1}}$.

Schnute growth model (OGLE 2016):

$$
M L=L_{1}+\left(L_{2}-L_{1}\right)\left[\frac{1-e^{-k\left(t-t_{1}\right)}}{1-e^{-k\left(t_{2}-t_{1}\right)}}\right]
$$

where $a, b, k, L_{1}, L_{2}, L_{3}$ are model parameters from the above five models to be estimated. For the Francis growth model $\mathrm{L}_{1}, \mathrm{~L}_{2}, \mathrm{~L}_{3}$ are mean length at ages $\mathrm{t}_{1}, \mathrm{t}_{2}$, $t_{3}, t_{1}$ and $t_{3}$ are ages of relatively young and old age individuals and $t_{2}=\frac{t_{1}+t_{3}}{2}$. For the Schnute growth model $\mathrm{L}_{1}, \mathrm{~L}_{2}$ are mean length at age $\mathrm{t}_{1}$ and $\mathrm{t}_{2}$, where $t_{1}$ and $t_{2}$ are ages of relatively young and old age individuals.

The four models (Linear, Power, Schnute and Francis) were fitted to length at age data for males and females separately, and to both sexes combined. 
Table 1a. Summary of mantle lengths (mm) corresponding to individuals collected during the November/December 2003 and 2004 research surveys that provided reliable estimates of age

\begin{tabular}{|c|c|c|c|c|c|c|c|c|}
\hline \multirow{2}{*}{$\begin{array}{l}\text { Sampling } \\
\text { period }\end{array}$} & \multirow{2}{*}{ Vessel (gear) } & \multicolumn{3}{|c|}{ Females } & \multicolumn{3}{|c|}{ Males } & \multirow{2}{*}{ Total (M \& F) } \\
\hline & & Total & Range & Mean \pm SE & Total & Range & Mean \pm SE & \\
\hline Nov/Dec 2003 & Algoa (jig) & 66 & $150-263$ & $205 \pm 2.46$ & 106 & $182-425$ & 4.16 & 172 \\
\hline Nov/Dec 2004 & $\begin{array}{c}\text { Algoa (jig) } \\
\text { Algoa (trawl) }\end{array}$ & $\begin{array}{r}123 \\
92\end{array}$ & $\begin{array}{c}83-240 \\
\text { (jig+trawl) }\end{array}$ & $176 \pm 1.78$ & $\begin{array}{r}134 \\
72\end{array}$ & $\begin{array}{c}71-375 \\
(\text { jig + trawl) }\end{array}$ & $244 \pm 5.07$ & 421 \\
\hline
\end{tabular}

Table 1b. Summary of estimated age distributions of male and female chokka squid collected during survey years 2003 and 2004 (quoted from LIPIŃSKI et al. 2020)

\begin{tabular}{ccccccc}
\hline \multirow{2}{*}{$\begin{array}{c}\text { Sampling } \\
\text { period }\end{array}$} & \multicolumn{5}{c}{ Estimated age (days) } \\
\cline { 2 - 7 } & Total no. & Remale & Mean \pm SE & Total no. & Range & Mean \pm SE \\
\hline Nov/Dec 2003 & 66 & $278-478$ & $350 \pm 5.58$ & 106 & $281-484$ & $364 \pm 4.50$ \\
Nov/Dec 2004 & 212 & $175-464$ & $326 \pm 2.70$ & 204 & $168-397$ & $325 \pm 3.15$ \\
\hline
\end{tabular}

Selection of the best performing model was based on the Akaike Information Criterion (AIC), Bayesian Information Criterion (BIC), Root Mean Squared Prediction Error (RMSPE) and Mean Absolute Error (MAE). Confidence intervals were estimated using a bootstrapping approach where, once the model is fitted, the residuals were randomly sampled and added to the response variable (length) and then the model was re-fitted. This process was repeated 1,000 times. Both the computation of the confidence intervals for the estimated parameters and the prediction are based on the bootstrap generated parameters. For all growth models fitted, the standard model diagnostics were checked: plots of residuals vs. fitted values (if models are valid this plot should show relatively random distribution of points), and quantile-quantile plots of residuals (to check if the residuals deviate from theoretical expectation under normal distribution).

Daily growth rate (mm/day) DGR and Instantaneous Growth Rate (IGR) were estimated as shown below for each 20-day interval, following RICKER (1979):

$$
\begin{gathered}
\text { DGR }=\frac{\mathrm{ML}_{1}-\mathrm{ML}_{2}}{\mathrm{t}_{1}-\mathrm{t}_{2}} \\
\mathrm{IGR}=\frac{\ln \left(\mathrm{ML}_{1}\right)-\ln \left(\mathrm{ML}_{2}\right)}{\mathrm{t}_{1}-\mathrm{t}_{2}}
\end{gathered}
$$

where $\mathrm{ML}_{1}$ and $\mathrm{ML}_{2}$ are the estimated/predicted mantle length at time $t_{1}$ and $t_{2}$, respectively. In addition to the point estimates, we also computed $95 \%$ confidence interval by bootstrapping as part of the growth model fitting.

All the analyses, visualisation and report generation were in R (R CORE TEAM 2020). Multiple R packages were utilised for data processing, visualisation, analysis, and summary of results including ALATHEA (2015), ELZHOV et al. (2016), HENRY \& WiCKHAM (2019), Allaire et al. (2020), RoBINSON \& HAYES (2020), WiCKHAM et al. (2020a, b) and XIE (2020).

\section{RESULTS}

The length frequency distributions of $L$. reynaudii for each of the years 2003 \& 2004 and for both years combined are presented in Figure 1 (Kernel density). The mantle length size ranged from 71 to $425 \mathrm{~mm}$ in males and from 83 to $263 \mathrm{~mm}$ in females during the two survey years.

The fits of the four growth models to the observed size at age data are illustrated in Figure 2. It is apparent that the Linear and Power models yield similar estimates of chokka squid growth, but these differ somewhat from those yielded by the Schnute and Francis models, which were almost identical. Plots of the residuals of the four growth models fitted to the data (Fig. 3) show no apparent systematic pattern, indicating no bias in the model estimates. The appreciably wider scatter of the residuals for males relative to females clearly shows the generally poorer fit of the models to the male data (apparent in the performance measures in Table 2). The Schnute and Francis growth models performed equally well in all fits to the data (Table 2) and showed better performance than did the linear and power models. The Francis growth model was, however, selected for further analyses of the year-specific data because the 
Schnute model could not be fitted (no convergence to a numerical solution) to all of the year-specific cases considered. The Francis model results (Table 3, Fig. 4) indicate that at relatively young ages, growth rates of male and female $L$. reynaudii were not appreciably different, but that as ages increased, males grew substantially faster than females. Separate Francis growth models fitted to size at age data for each sampling year (2003 and 2004) show that the growth of the squid sampled in 2003 appears to be faster than that of those sampled in 2004 (Fig. 5), and that males in both years grew faster in length with increasing age compared to females. The Linear growth model (Table 4) provided an "overall" measure of growth rate as an increase in size per day: 0.75-1.02 $\mathrm{mm} / \mathrm{d}$ for males, $0.32-0.45 \mathrm{~mm} / \mathrm{d}$ for females and $0.64-0.86 \mathrm{~mm} / \mathrm{d}$ for sexes combined.

The DGR and instantaneous growth rate $(G)$ generally declined with age and appeared to vary between sex (Figs 6-7).
Table 2. Performance measures for four growth models (Linear, Francis, Power and Schnute) and different data types (All data, Male, and Female). Four model performance measures were considered: Akaike Information Criterion (AIC), Bayesian Information Criterion (BIC), Root Mean Squared Error (RMSE), and Mean Absolute Error (MAE)

\begin{tabular}{clcccc}
\hline sex & model_name & AIC & BIC & RMSE & MAE \\
\hline All & Francis & 6325.39 & 6342.79 & 59.96 & 50.60 \\
& Linear & 6326.80 & 6339.86 & 60.14 & 50.58 \\
& Power & 6327.48 & 6340.54 & 60.17 & 50.75 \\
\multirow{4}{*}{ Male } & Schnute & 6325.39 & 6342.79 & 59.96 & 50.60 \\
& Francis & 3307.88 & 3322.75 & 55.06 & 42.37 \\
& Linear & 3312.42 & 3323.57 & 55.66 & 43.77 \\
& Power & 3313.65 & 3324.80 & 55.77 & 43.95 \\
\multirow{5}{*}{ Female } & Schnute & 3307.88 & 3322.75 & 55.06 & 42.37 \\
& Francis & 2437.49 & 2451.87 & 22.13 & 17.28 \\
& Linear & 2456.88 & 2467.66 & 23.03 & 18.09 \\
& Power & 2452.78 & 2463.57 & 22.85 & 17.94 \\
& Schnute & 2437.49 & 2451.87 & 22.13 & 17.28 \\
\hline
\end{tabular}

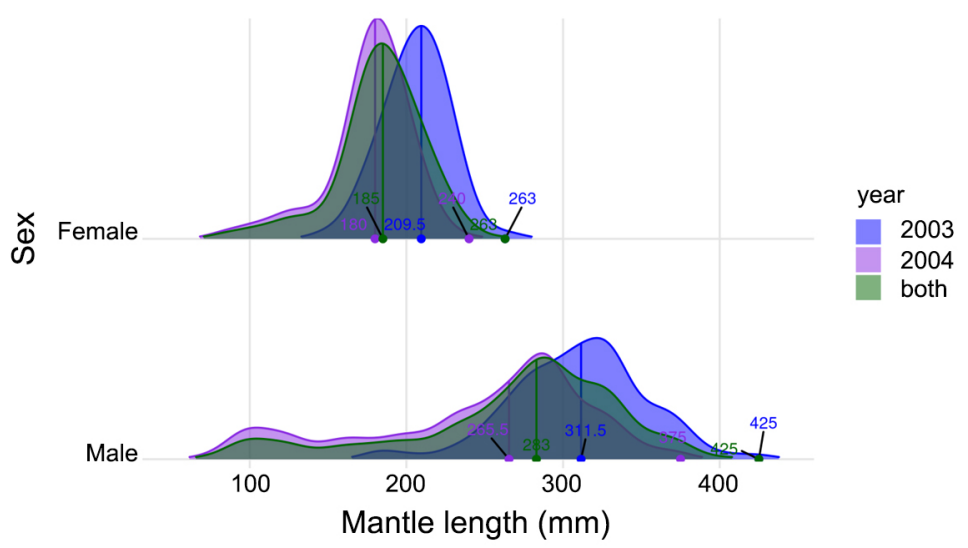

Fig. 1. Female and male length distribution of Loligo reynaudii between Plettenberg Bay and Port Alfred for the surveys conducted during November/December of 2003 and 2004. Median and maximum length of squid for each sex and year are represented by the dots. Kernel density graph, therefore there is no y axis

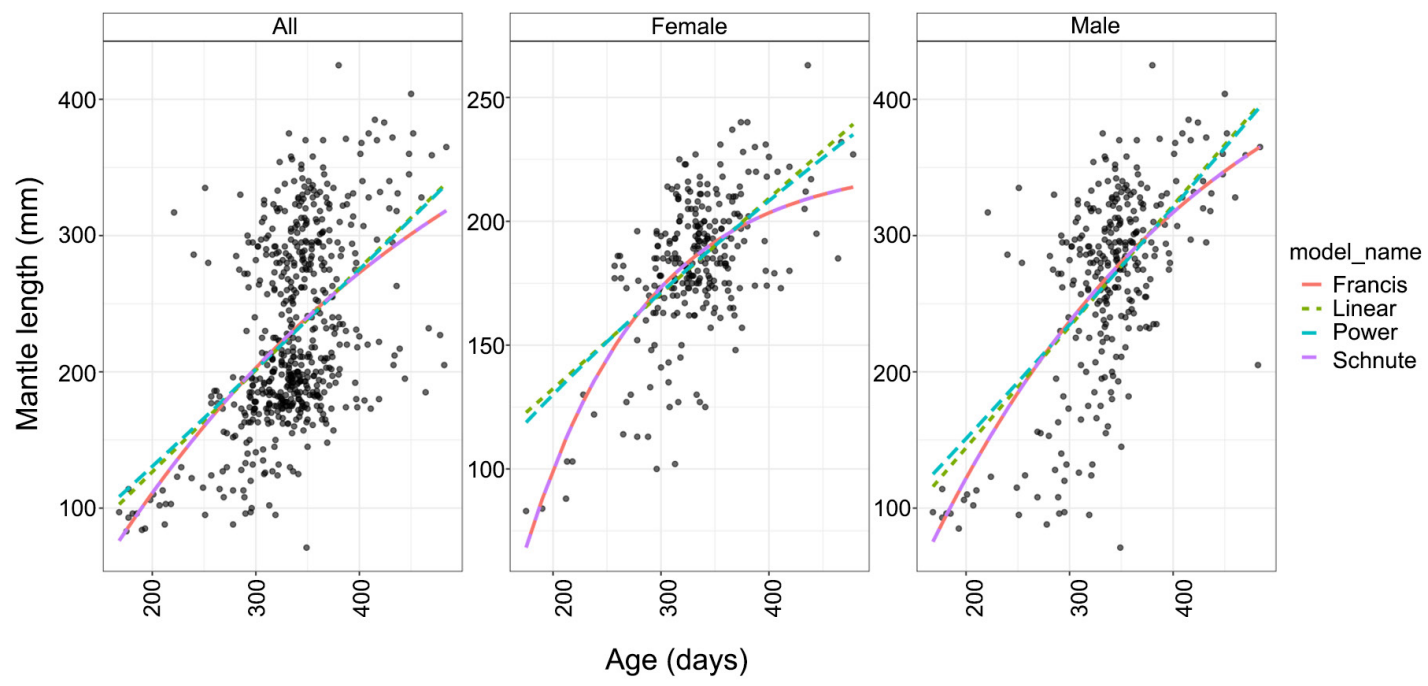

Fig. 2. Fits from the four growth models (Francis, Power, Linear and Schnute) for males, females, and all individuals combined 


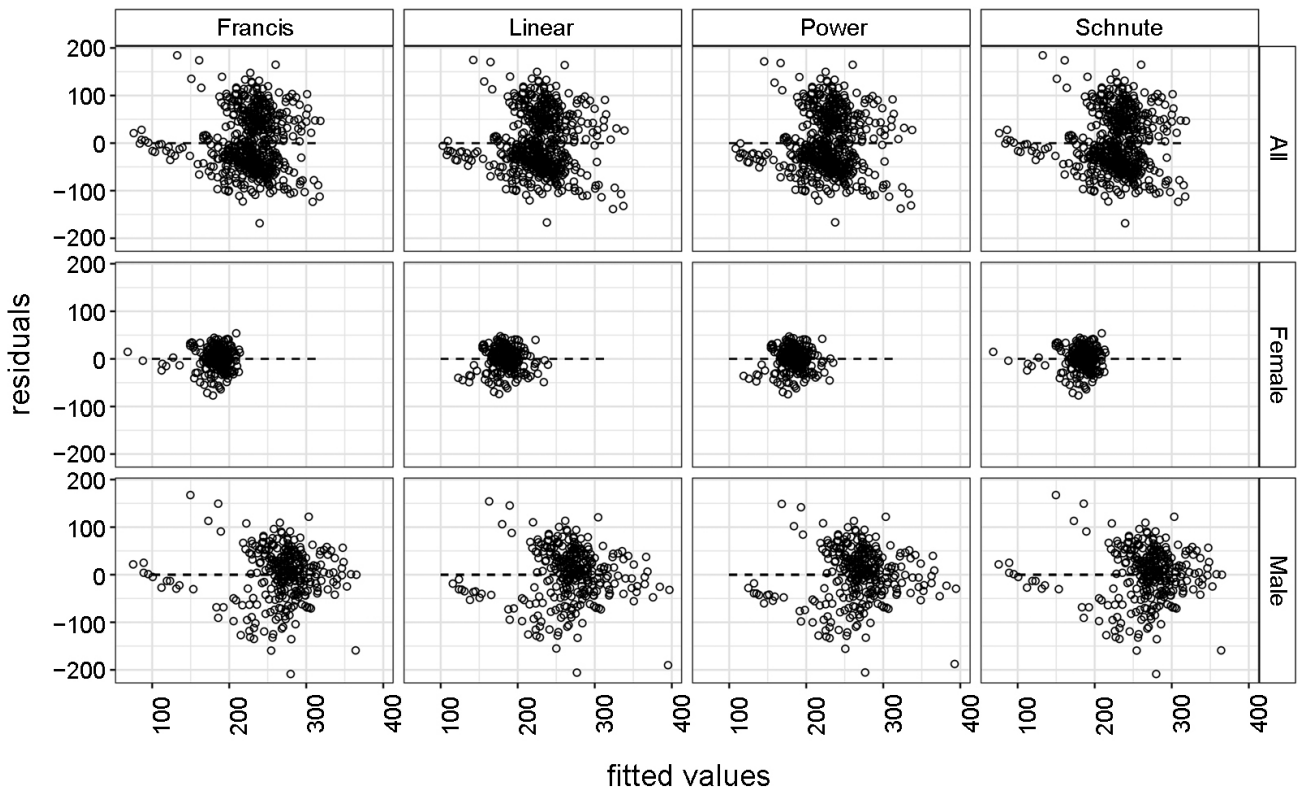

Fig. 3. Residual plots for the four growth models fitted to the size at age data for males, females and all combined
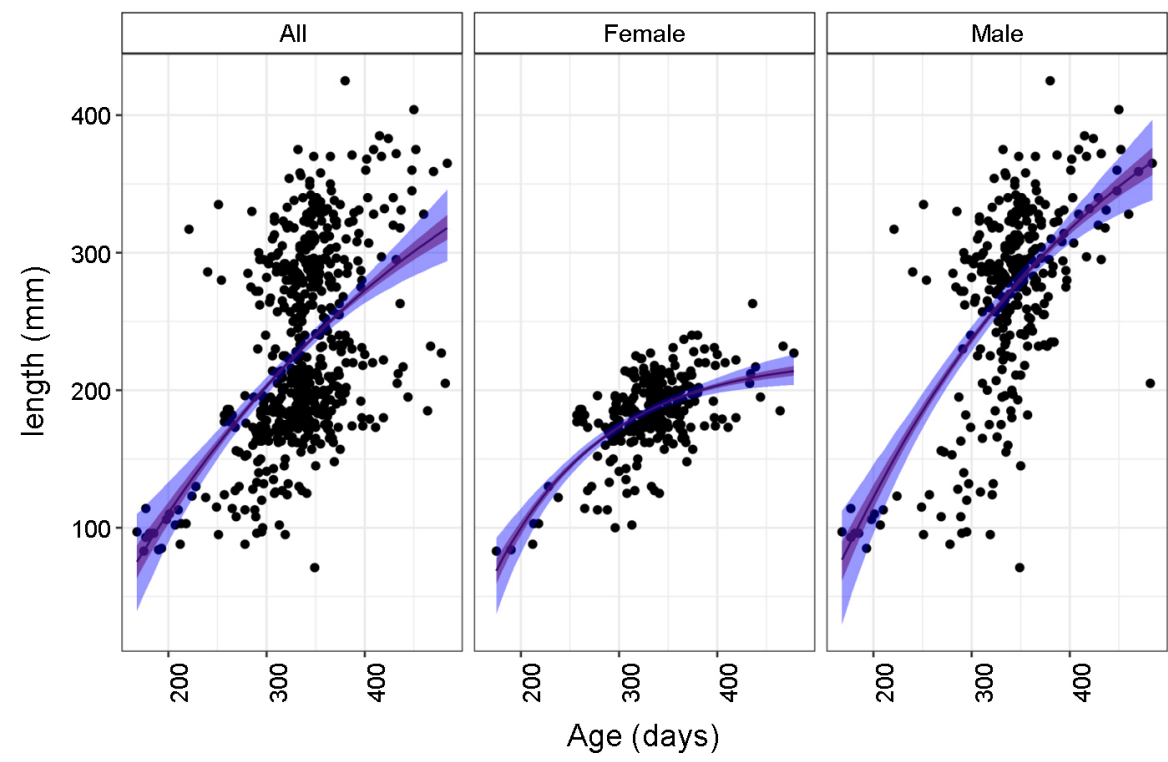

Fig. 4. Sex-specific observed mantle lengths (mm) at age (dots) pooled for both sampling years (2003 and 2004), with the Francis growth models fitted to the data. Solid lines represent the median of predicted mantle length. Light brown and light blue envelopes represent the $50 \%$ and $95 \%$ confidence intervals, respectively

Table 3. Summary statistics (median, upper and lower $2.5 \%$ quantiles) of estimated growth parameters for males, females and all data combined. Francis growth model

\begin{tabular}{lcrrc}
\hline \multicolumn{1}{c}{ sex } & terms & \multicolumn{1}{c}{ quant_2.5 } & quant_50 & quant_97.5 \\
\hline All & L1 & 88.13 & 110.99 & 132.82 \\
& L2 & 196.63 & 202.97 & 209.56 \\
\multirow{4}{*}{ Female } & L3 & 262.87 & 272.27 & 281.99 \\
& L1 & 81.57 & 99.42 & 116.03 \\
& L2 & 169.53 & 173.28 & 177.01 \\
Male & L3 & 197.94 & 203.45 & 208.80 \\
& L1 & 94.10 & 122.20 & 147.02 \\
& L2 & 228.58 & 236.85 & 245.40 \\
& L3 & 305.71 & 317.48 & 327.50 \\
\hline
\end{tabular}

Table 4. Summary statistics of estimated growth parameters for males, females and all data combined. Linear growth model

\begin{tabular}{lcrrr}
\hline \multicolumn{1}{c}{ sex } & terms & \multicolumn{1}{c}{ quant_2.5 } & quant_50 & quant_97.5 \\
\hline All & $\mathrm{a}$ & -59.35 & -23.65 & 12.04 \\
& $\mathrm{~b}$ & 0.64 & 0.75 & 0.86 \\
Female & $\mathrm{a}$ & 33.49 & 56.14 & 76.70 \\
& $\mathrm{~b}$ & 0.32 & 0.38 & 0.45 \\
Male & $\mathrm{a}$ & -79.28 & -34.65 & 13.10 \\
& $\mathrm{~b}$ & 0.75 & 0.89 & 1.02 \\
\hline
\end{tabular}




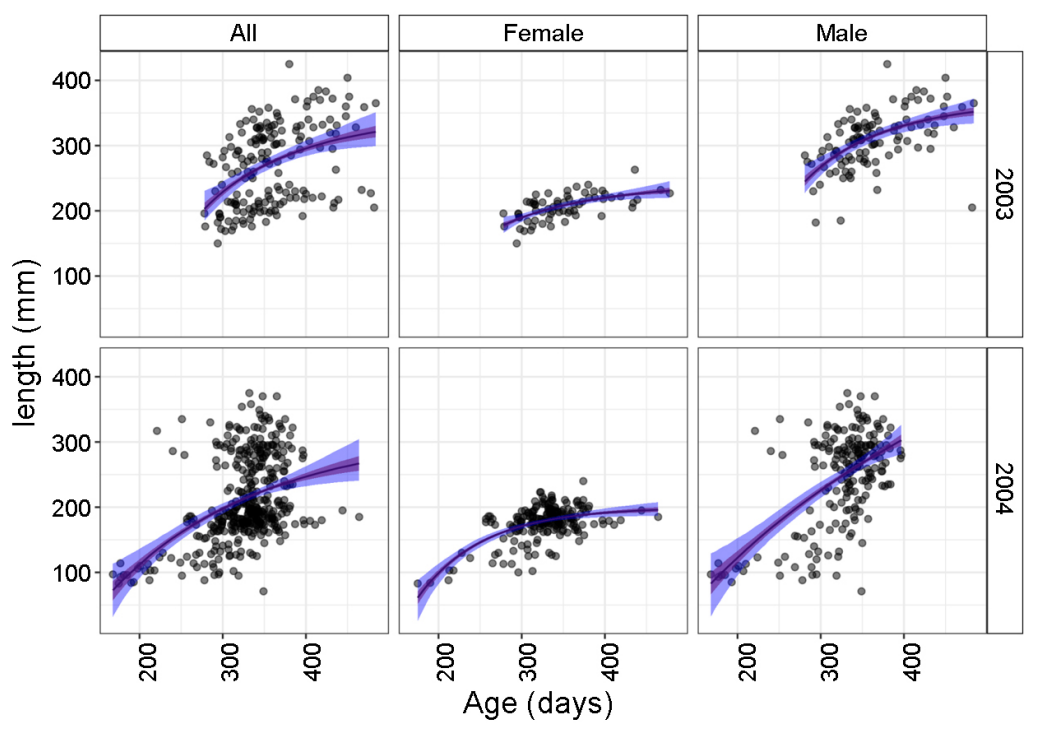

Fig. 5. Year-specific observed mantle lengths at age (dots) with the Francis growth models fitted to the data. Solid lines represent the median of predicted mantle length. Light brown and light blue envelopes represent the 50\% and $95 \%$ confidence intervals, respectively

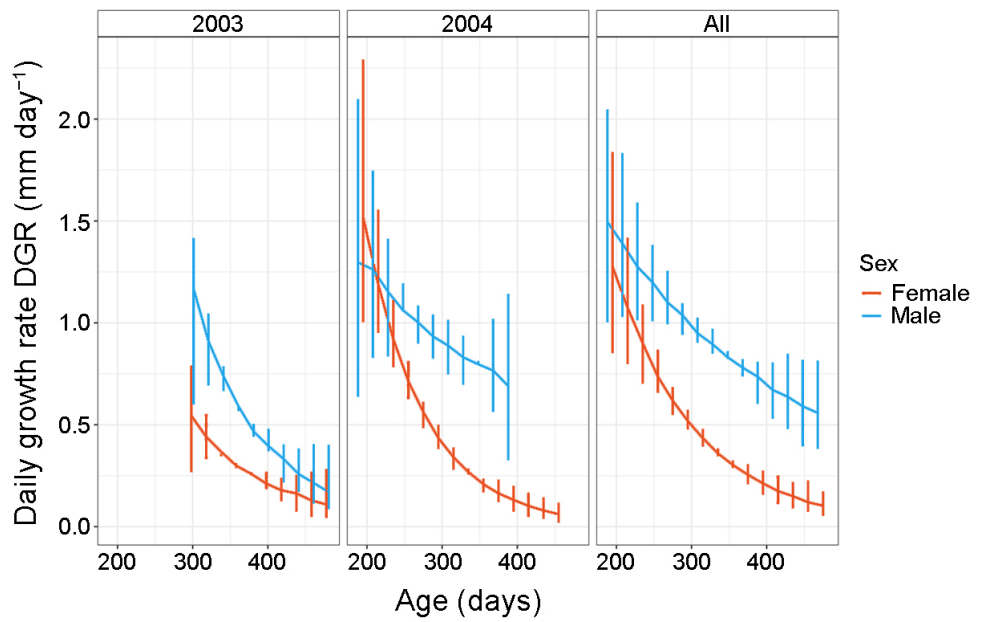

Fig. 6. Daily growth rates, mantle size (mm/day) for females and males for the two sampling years (2003 and 2004$)$ and the combined data. Error bars represent $95 \%$ confidence interval

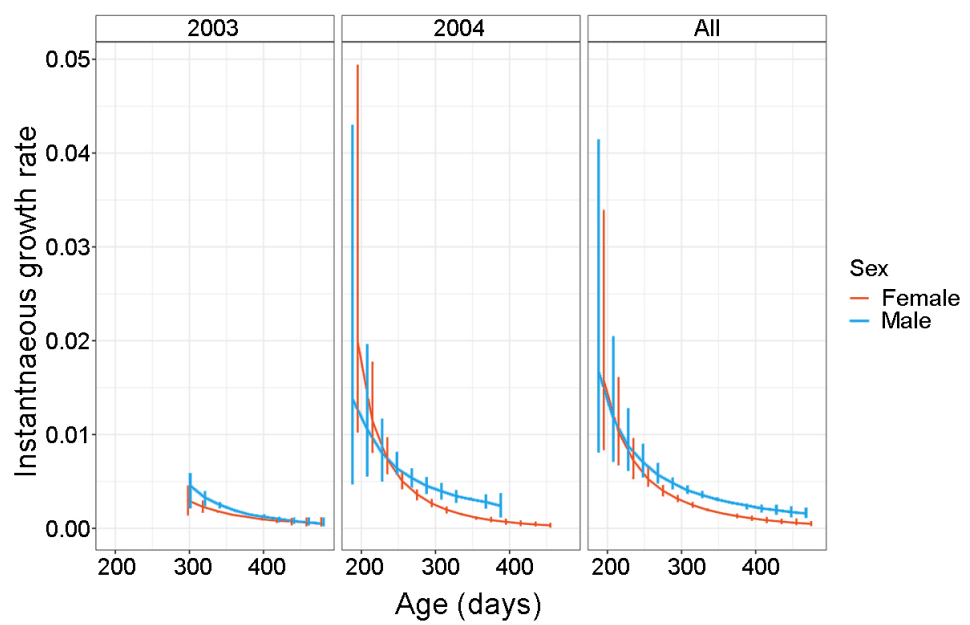

Fig. 7. Instantaneous growth rate for females and males for the two sampling years (2003 and 2004) and the combined data. Error bars represent $95 \%$ confidence interval 


\section{DISCUSSION}

Considering that the data used in this study only covered the middle and later parts of the chokka squid life cycle and that the data were collected in a limited part of the species distribution range, we note that growth of the whole population of chokka cannot be discussed here. Likewise, precision of age readings (e.g. CAMPANA 2001) was somewhat compromised, due to logistical reasons, by the use of only one statolith reader (albeit experienced in reading both otoliths and statoliths) and only one reading, as in the linked study by LIPIŃSKI et al. (2020). However, it is believed that in the light of the present results being comparable with a previous study (LIPIŃSKI \& DURHOLTZ 1994 vs. LIPIŃSKI et al. 2020) these results may be accepted, and outweigh rejection on the grounds that the requirement of precision is not met. The growth rates in this paper concern adult life stages of a single, but very important and exploited cohort. GRIST et al. (2011) have warned against spurious growth models and equations arising from uncritical lumping of various cohorts with drastically different growth trajectories and patterns. The linear models fitted to the data during this study suggested that the relative growth rates of the chokka squid may be low in comparison with other values for loliginids. For example, JiN et al. (2019) found that such values for Uroteuthis chinensis (Gray, 1849) were 5.17 $\mathrm{mm} / \mathrm{d}$ and $2.46 \mathrm{~mm} / \mathrm{d}$ for males and females, respectively; for U. edulis (Hoyle, 1885) they were: males $1.71 \mathrm{~mm} / \mathrm{d}$, females $2.05 \mathrm{~mm} / \mathrm{d}$. This may be characteristic for the older life stages where growth rates are declining (NATSUKARI et al. 1988, SCHWARZ \& PEREZ 2010).

Interestingly, $L$. reynaudii resembles $U$. chinensis in that the growth of males is more than double that of females. While the results of this study have therefore confirmed the sexual dimorphism in the chokka squid growth and highlighted the large inter-annual variation in growth (Figs 6-7), further work encompassing data from all life stages, seasons, areas and as many years as possible is required for a proper understanding and quantification of the growth of this species. However, growth rates from a single cohort of squid, investigated on a large sample and repeated for at least two years, highlight growth ranges, differences between sexes, differences between years, and growth type (slow - fast; variable - steady) (Figs 6-7). This simple material shows some possible interpretation complications, such as possible limited presence of sneaker males in the sample, which may have similar ages as large males but, obviously, very different growth rates (references concerning sneaker presence: SAUER et al. 2013). In addition, difference in growth between years may have been influenced by the different sampling methods, where 2003 data were collected only by jigging and 2004 data were collected both by jigging and trawl. However, this influence is considered small as ages (LIPIŃSKI et al. 2020) and length frequencies (Fig. 1) for both years were similar for smaller squid, especially males.

There are a number of reviews on growth in cephalopods (JACKSON 1994, LIPIŃSKI 2002, ARKHIPKIN 2004, JACKSON \& MCGLASHAN 2004, ARKHIPKIN \& ROA-URETA 2005) as well as some more recent considerations (e.g. SCHWARZ \& PEREZ 2010, GRIST et al. 2011, JiN et al. 2019). It has been recognised that understanding and describing cephalopod growth are difficult (MOLTSCHANIWSKYJ 2004). Early studies (eg. JACKSON 1990, GONZALEZ et al. 1996) suggested that growth of squid could best be described by a linear model. Other studies (e.g. YANG et al. 1986, LEE et al. 1994, HATFIELD et al. 2001) reported considerable differences between growth models of cephalopods grown in different conditions (e.g. in different temperature regimes). ARKHIPKIN (2004) pointed out that maximum relative growth rates were observed during the paralarval stage, quoting FORSYTHE \& HEUKELEM's (1987) data. However, these data were obtained for paralarvae kept in aquaria (therefore fed ad libitum) and not in their natural environment (see also GRIST et al. 2011: p. 117). At least some data from the latter (e.g. NATSUKARI et al. 1988, BIGELOW 1992) show the opposite: the initial phase of paralarval growth is in fact the slowest stage (BIGELOW 1992: fig. 7, first few days; VIDAL et al. 2002: reporting "no net growth" during the first 10-15 days), despite exponential growth phase later. If this is confirmed with a larger sample size and for many species, a three-phase growth for cephalopods may be most plausible: paralarval (linear followed by exponential during the "vertical movement" phase of the paralarvae), juvenile and early adult (exponential); late adult (asymptotic), as was suggested by JACKSON (2004) working with loliginid squid.

The large individual variation has led to two different approaches in considering cephalopod growth: fitting available models to available length and/or weight data (most often in situ, but also from aquarium rearing) (e.g. ARKHIPKIN \& ROA-URETA 2005); or open-ended, flexible, currently energy balance-based models (GRIST \& JACKSON 2004, O'DOR et al. 2005, GRIST et al. 2011). However, given that growth models typically do not fit squid size at age data very well (NATSUKARI et al. 1988, SCHWARZ \& PEREZ 2010, present data: Fig. 2) and energy balance equations are generally too broad, lacking useful detail and resolution, we are of the opinion that estimates of growth rate changes over time (e.g. ARKHIPKIN 1994: 
fig. 9-10, ARKHIPKIN et al. 1999: fig. 9EF, present paper: Figs 6-7) are more useful to evaluate squid growth during the full life cycle. Of course, it should be appreciated that even if they cover the entire life cycle, they are imprecise in determining the lower and especially upper growth rates for a given species. This is because of large natural variability in that part of the life cycle, including responses to, for example, environmental factors, food availability etc. (NATSUKARI et al. 1988). A full understanding of these fluctuations and their determinants is (ideally) required for accurate life cycle models, population dynamics models, and fisheries management decisions.

\section{REFERENCES}

AlatheA L. 2015. Captioner: numbers figures and creates simple captions. Available online at https://rdrr.io/ cran/captioner/ (accessed 25 February 2021).

Allaire J., XiE Y., McPherson J., Luraschi J., UsheY K., ATKins A., WiCKham H., Cheng J., CHANG W., IANNONE R., DUNNING A., YASUMOTO A., SCHLOERKE B., Sievert J., DervieuX C., RYAN M., Aust F., AlleN J., SEO J.Y., BARRETT M., HYNDMAN R., LESUR R., STOREY R., ARSLAN R., OlLER S. 2020. R markdown: Dynamic documents for $\mathrm{r}$. Available on line at https:// CRAN.R-project.org/package $=$ rmarkdown $\quad$ (accessed 25 February 2021).

ARKHIPKIN A. I. 1994. Age, growth and maturation of the squid Enoploteuthis leptura (Oegopsida: Enoploteuthidae) from the central-east Atlantic. Journal of Molluscan Studies 60: 1-8.

https://doi.org/10.1093/mollus/60.1.1

ARKHIPKIN A .I. 2004. Diversity in growth and longevity in short-lived animals: squid of the suborder Oegopsina. Marine and Freshwater Research 55: 341-355. https://doi.org/10.1071/MF03202

ARKHIPKIN A. [I.], LAPTIKHOVSKY V., GOLUB A. 1999. Population structure and growth of the squid Todarodes sagittatus (Cephalopoda: Ommastrephidae) in northwest African waters. Journal of the Marine Biological Association of the U.K. 79: 467-477. https://doi.org/10.1017/S0025315498000599

ARKHIPKIN A. I., ROA-URETA R. 2005. Identification of ontogenetic growth models for squid. Marine and Freshwater Research. 56: 371-386. https://doi.org/10.1071/MF04274

BigelOW K. A. 1992. Age and growth in paralarvae of the mesopelagic squid Abralia trigonura based on daily growth increments in statoliths. Marine Ecology Progress Series 82: 31-40.

https://doi.org/10.3354/meps082031

CAMPANA S. E. 2001. Accuracy, precision and quality control in age determination, including a review of the use and abuse of age validation methods. Journal of Fish Biology 59: 197-242.

https://doi.org/10.1111/j.1095-8649.2001.tb00127.x

\section{ACKNOWLEDGEMENTS}

The South African Squid Management Industrial Association (SASMIA) is acknowledged for funding the project, and the former Department of Agriculture, Forestry and Fisheries for access to the data. Many of our professional colleagues participated in the data collection - their input is gratefully acknowledged. Prof. COLEEN MOLONEY (UCT) and Dr LISA HENDRICKSON (NMFS NOAA, USA) are thanked for the discussions on cephalopod growth and various comments and inputs. Finally, The Rhodes University (Department of Ichthyology and Fisheries Science) provided logistics and support.

ElZHOV T. V., Mullen K. M., SPIESS A.-N., BOLKeR B. 2016. Minpack.lm: R interface to the Levenberg-Marquardt nonlinear least-squares algorithm found in minpack, plus support for bounds. Available online at https:// CRAN.R-project.org/package $=$ minpack.lm $\quad$ (accessed 25 February 2021).

FORSYTHE J. W., HEUKELEM W. F. VAN 1987. Growth. In: BOYLE P. R. (ed.). Cephalopod life cycles. Vol. II, comparative reviews. Academic Press, London, pp.135-156.

Gonzalez A. F., Castro B. G., Guerra A. 1996. Age and growth of the short-finned squid Illex coindetii in Galician waters (NW Spain) based on statolith analysis. ICES Journal of Marine Science 53: 802-810. https://doi.org/10.1006/jmsc.1996.0101

GRIST E. P. M., JACKSON G. D. 2004. Energy balance as a determinant of two-phase growth in cephalopods. Marine and Freshwater Research 55: 395-401.

https://doi.org/10.1071/MF03154

Grist E. P. M., JACKSON G. D., MEEKAN M. G. 2011. Does a snapshot show the whole picture? Intrinsic limitations to growth inference of the short lived and fast growing. Environmental Biology of Fishes 90: 111-120. https://doi.org/10.1007/s10641-010-9723-9

HATANAKA H. 1986. Growth and life span of short-finned squid Illex argentinus in the waters off Argentina. Bulletin of the Japanese Society of Scientific Fisheries 52: 11-17. https://doi.org/10.2331/suisan.52.11

Hatfield E. M. C., HANlON R. T., FORSythe J. W., GRist E. P. M. 2001. Laboratory testing of a growth hypothesis for juvenile squid Loligo pealeii (Cephalopoda: Loliginidae). Canadian Journal of Fisheries and Aquatic Sciences 58: 845-857. https://doi.org/10.1139/f01-030

HenRY L., WiCKham H. 2019. Purrr: Functional programming tools. Available online at https://CRAN.R-project. org/ package = purrr. (Accessed 25 February 2021)

JACKSON G. D. 1990. Age and growth of the tropical nearshore loliginid squid Sepioteuthis lessoniana determined from statolith growth-ring analysis. Fishery Bulletin U.S. 88: 113-118. 
JACKSON G. D. 1994. Application and future potential of statolith increment analysis in squids and sepioids. Canadian Journal of Fisheries and Aquatic Sciences 51: 2612-2625. https://doi.org/10.1139/f94-261

JACKSON G. D. 2004. Advances in defining the life histories of myopsid squid. Marine and Freshwater Research 55: 357-365. https://doi.org/10.1071/MF03152

JACKSON G. D., MCGLASHAN D. J. (eds). 2004. Cephalopod growth. Marine and Freshwater Research 55: 327-446. https://doi.org/10.1071/MF04075

JIN Y., LI N., CHEN X., LIU B., LI J. 2019. Comparative age and growth of Uroteuthis chinensis and Uroteuthis edulis from China Seas based on statolith. Aquaculture and Fisheries 4: 166-172. https://doi.org/10.1016/j.aaf.2019.02.002

LEE P. G., TURK P. E., YANG W. T., HANLON R. T. 1994 Biological characteristics and biomedical applications of the squid Sepioteuthis lessoniana cultured through multiple generations. Biological Bulletin 186: 328-341. https://doi.org/10.2307/1542279

LIPIŃSKI M. R. 2002. Growth of cephalopods: a conceptual model. Abhandlungen der Geologischen Bundesanstalt 57: 133-138.

LIPIŃSKI M. R., DURHOLTZ M. D. 1994. Problems associated with ageing squid from their statoliths: towards a more structured approach. Antarctic Science 6: 215222.

https://doi.org/10.1017/S0954102094000337

LiPIŃSKI M. R., HAMPTON I., SAUER W. H. H., AUGUSTYN C. J. 1998. Daily net emigration from a spawning concentration of chokka squid (Loligo vulgaris reynaudii d'Orbigny, 1845) in Kromme Bay, South Africa. ICES Journal of Marine Science 55: 258-270. https://doi.org/10.1006/jmsc.1997.0271

LIPIŃSKI M. R., MWANANGOMBE C. H., DuRHOlTZ D., Yemane D., Githaiga-Mwicigi J., SAUeR W. H. H. 2020. Age estimates of chokka squid (Loligo reynaudii d'Orbigny, 1845) off South Africa and their use to test the effectiveness of a closed season for conserving this resource. African Journal of Marine Science 42: 461471.

https://doi.org/10.2989/1814232X.2020.1842804

LIPIŃSKI M. R., UNDERHILL L. G. 1995. Sexual maturation in squid: quantum or continuum? South African Journal of Marine Science 15: 207-223. https://doi.org/10.2989/02577619509504844

LIPIŃSKI M. R., VYVER J. S. F. VAN DER, SHAW P., SAUER W. H. H. 2016. Life cycle of chokka squid Loligo reynaudii in South African waters. African Journal of Marine Science 38: 589-593.

https://doi.org/10.2989/1814232X.2016.1230074

MOLTSCHANIWSKYJ N. A. 2004. Understanding the process of growth in cephalopods. Marine and Freshwater Research 55: 379-386. https://doi.org/10.1071/MF03147

NATSUKARI Y., NAKANOSE T., ODA K. 1988. Age and growth of loliginid squid Photololigo edulis (Hoyle,
1885). Journal of the Experimental Marine Biology and Ecology 116: 177-190.

https://doi.org/10.1016/0022-0981(88)90054-8

O’DOR R., AITKEN J., JACKSON G. D. 2005. Energy balance growth models: applications to cephalopods. Phuket Marine Biological Center Research Bulletin 66: 329336.

OGLE D. H. 2016. Introductory fisheries analyses with R. Vol. 32. CRC Press, Boca Raton. https://doi.org/10.1201/b19232

R CORE TEAM. 2020. R: A language and environment for statistical computing. R Foundation for Statistical Computing, Vienna, Austria. Available online at https:// www.R-project.org/ (Accessed 25 February 2021).

RICKER W. E. 1979. Growth rates and models. In: HOAR W. S., RANDALL D. J., BRETT J. R. (eds). Fish Physiology, III, Bioenergetics and Growth, Academic Press, New York, pp. 677-743. https://doi.org/10.1016/S1546-5098(08)60034-5

RoBinson D., HAYES A. 2020. Broom: Convert statistical analysis objects into tidy tibbles. Available online at https://CRAN.R-project.org/package $=$ broom (Accessed 25 February 2021).

SAUER W. H. H., SMAlE M. J., LiPIŃSKI M. R. 1992. The location of the spawning grounds, spawning and schooling behaviour of the squid Loligo vulgaris reynaudii (Cephalopoda: Myopsida) off the Eastern Cape coast, South Africa. Marine Biology 114: 97-107. https://doi.org/10.1007/BF00350859

SAUER W. H. H., DOWNEY N. J., LIPIŃSKI M. R., ROBERTS M. J., Smale M. J., Shaw P., Glazer J., Melo Y. 2013. Loligo reynaudii, Chokka Squid. In: RosA R., O'DoR R., PIERCE G. (eds). Advances in squid biology, ecology and fisheries. Part 1. Nova Science Publishers, Inc., Hauppauge, New York, pp. 33-64.

SCHWARZ R., PEREZ J. A. A. 2010. Growth model identification of short-finned squid Illex argentinus (Cephalopoda: Ommastrephidae) off southern Brazil using statoliths. Fisheries Research 106: 177-184. https://doi.org/10.1016/j.fishres.2010.06.008

Vidal E. A. G., Dimarco F. P., Wormuth J. H., LeE P. G. 2002. Influence of temperature and food availability on survival, growth and yolk utilization in hatchling squid. Bulletin of Marine Science 71: 915-931.

VYVER J. S. F. VAN DER, SAUER W. H. H., MCKEOWN N. J., YeMANe D., SHAW P. W., LiPińSKI M. R. 2016. Phenotypic divergence despite high gene flow in chokka squid Loligo reynaudii (Cephalopoda: Loliginidae): implications for fishery management. Journal of the Marine Biological Association of the United Kingdom 96: 1507-1525.

https://doi.org/10.1017/S0025315415001794

WickHam H., Chang W., Henry L., Pedersen T. L., TAKAHASHI K., WILKE C., WOO K., YUTANI H., DunNINGTON D. 2020a. Ggplot2: Create elegant data visualisations using the grammar of graphics. Available online at https://CRAN.R-project.org/package=ggplot2 (Accessed 25 February 2021).

WickHam H., Francois R., HenRY L., MÜller K. 2020 b. Dplyr: A grammar of data manipulation. Available on- 
line at https://CRAN.R-project.org/package=dplyr (Accessed 25 February 2021).

XIE Y. 2020. Knitr: A general-purpose package for dynamic report generation in $\mathrm{r}$. Available online at https:// CRAN.R-project.org/package $=$ knitr (Accessed on 25 February 2021).

YANG W. T., HiXON R. F., TURK P. E., KRejCi M. E., HUlET W. H., HANLON R. T. 1986. Growth, behavior, and sexual maturation of the market squid, Loligo opalescens, cultured through the life cycle. Fishery Bulletin U.S. 84: 771-798.

Received: March 22nd, 2021 Revised: May 1st/June 14th, 2021 Accepted: June 23rd, 2021 Published on-line: July 11th, 2021 